\title{
KONSEP KEPERAWANAN TERHADAP PEMBATALAN PERKAWINAN TIJAUAN HUKUM ISLAM DAN FEMINISME
}

\author{
Nada Putri Rohana \\ IAIN Padang Sidumpuan \\ Mustafid \\ IAIN Padang Sidumpuan
}

\begin{abstract}
Abstrak
Keperawanan sebenarnya memiliki berbagai konsep, yaitu di Indonesia konsep keperawanan wanita adalah selaput darah atau selaput darah masih utuh atau konsep perawan dengan adanya darah perawan. Konsep tersebut dianggap urgen dalam pernikahan sehingga menimbulkan pelecehan yang dapat mengganggu keutuhan dan keharmonisan rumah tangga. Konsep keperawanan bisa menjadi syiqaq (perselisihan/sengketa) sehingga muncul stigma sebagai alasan batalnya pernikahan. Mengenai batalnya perkawinan rentan terkait masalah ini dikaitkan dengan KHI Pasal 72 ayat (2), kemudian tentang alasan atau alasan perceraian dalam KHI Pasal 116 huruf f. Penelitian ini menunjukkan bahwa konsep keperawanan mengalami evolusi hukum yang kompleks dan sensitif dalam kehidupan sosial, budaya dan agama bahkan dalam rumah tangga. Konsep keperawanan terhadap batalnya perkawinan dalam perspektif hukum Islam dan feminisme menghadirkan sebab-akibat, yaitu: (hifdz al- din) memelihara agama (dengan meluruskan niat dalam perkawinan dan menambahkan iman dalam diri dan jiwa untuk kesungguhan dalam tujuan perkawinan). ), (hifdz al- nafs ) memelihara diri (larangan mendekati zina, dan keharusan menjaga kemaluan serta pandangan dan larangan menghina pasangan dengan tuduhan dzolim), (hifdz alnas) memelihara keturunan dan kehormatan (dengan menjaga dan memahami aturan-aturan dalam perkawinan yang berkaitan dengan hak dan kewajiban), (hifdz al-mal) menjaga harta (bahwa wanita adalah perhiasan, pakaian bagi suami, sebaliknya, ladang bagi suami, adalah harta). harta dan kehormatan suamisehingga harus dijaga dengan aib), dan (hifdz al-'aql) memelihara akal (keharusan menuntut ilmu sebagai sarana bagi laki-laki atau perempuan untuk membuka pola pikirnya dalam memahami kehidupan pernikahan adalah masalah hubungan seksual, perlu pendidikan seksual yang sehat agar terhindar dari stigma atau kecurigaan atau kecemasan yang mengganggu kehidupan rumah tangga). Sehingga dapat mengontrol kehidupan masyarakat sesuai dengan konsep hukum guna meluruskan spekulasi stigma.
\end{abstract}

Kata Kunci: Keperawanan, stigma, syiqaq. 


\section{Abstrack}

Virginity in fact has a variety of concepts, namely in Indonesia the concept of female virginity is that the blood membrane or hymen is still intact or a virgin concept in the presence of virgin blood. The concept is considered urgent in marriage so that it causes harassment which can disrupt the integrity and harmony of the household. The concept of virginity can be a syiqaq (disputes / disputes) so that stigma arises as reasons for canceling marriages. Regarding the cancellation of vulnerable marriages related to this issue is associated with KHI Article 72 paragraph (2), then about the reasons or reasons for divorce in KHI Article 116 letter f. This research shows that the concept of virginity undergoes a complex and sensitive evolution of law in social, cultural and religious life even in the household. The concept of virginity towards the annulment of marriage in the perspective of Islamic law and feminism presents causation, namely: (hifdz al-din) nurturing religion (by rectifying intentions in marriage and adding faith in oneself and soul to earnest in the purpose of marriage), (hifdz al-nafs ) nurturing oneself (the prohibition of approaching adultery, and the necessity of guarding the genitals and the view and prohibition of insulting the partner with allegations of dzolim), (hifdz al-nas / irdl) maintaining offspring and honor (by guarding and understanding the rules in marriage related to rights and obligations), (hifdz al-mal) preserves property (that the woman is jewelry, is clothing for the husband, vice versa, is the field for the husband, is the property and honor of the husband so that it must be safeguarded by disgrace), and (hifdz al - 'aql) maintains the mind (the necessity to study as a means for men or women to open their mindset in understanding the life of the pern ikahan is a matter of sexual relations, needs healthy sexual education in order to avoid stigma or suspicion or anxiety that disrupts domestic life). Thus, it can control people's lives in accordance with the legal concept in order to rectify stigma speculation.

Kata Kunci: Virginity, stigma, syiqaq.

\section{A. Pendahuluan}

Perkawinan merupakan cara untuk menghalalkan sesuatu yang haram dengan adanya ijab dn qabul. Perkawinan juga akan menimbulkan sebuah hukum yang berupa halalnya melakukan jimak antara pria dan wanita, serta adanya tanggung jawab di antara keduanya dan membuat adanya hak dan kewajiban. ${ }^{1}$ Seseorang sangat membutuhkan penyaluhan hasrat birahi dalam memenuhi kebutuhan bathinnya, maka dalam perkawinan akan mendapatkan penyaluran tersebut dengan cara yang baik.

Perkawinan berasal dari kata kawin/nikah (نكاح), secara luhgo berarti mengumpulkan dan dipakai juga untuk pengertian jimak. Kata nikah juga dimaknai

${ }^{1}$ Muhammad Abu Zahra, al Ahwal al Syakhsiyyah (Qahirah: Dar al Fikr al 'Arabi, 1957) 
dengan persetubuhan, dan juga di maknai dengan diperbolehkan antara perempuan dan pria untuk melakukan jimak. ${ }^{2}$ Sebuah perkawinan di awali dengan ijab dan qabul, maka barulah diperbolehkan aktivitas jimak tersebut. Maka sering di masyarakat istilah malam pertama, yang berarti untuk pertama kali melakukan jimak, Hal itu berarti tidak ada malam pertama bagi pasangan yang telah melakukan senggama sebelum acara perkawinan.

Pandangan yang menyebutkan bahwa seorang wanita dikatakan perawan, jika pada malam pertama mengalami pendarahan atau robeknya selaput perawan pada wanita tersebut. Sehingga seorang pria sangat kecewa ketika malam pertama tidak adanya pendarahan. Hal ini menjadi stigma di dalam perkawinan bahwa ketika tidak adanya pendarahan waktu berjimak di malam pertama, maka seorang pria akan menceraikan atau mempulangkan wanita tersebut ke orang tuanya dan disitu terjadilah pembatalan perkawinan.

Konsep keperawanan di Indonesia pada umumnya adalah selaput darah wanita tersebut masih utuh dan belum tersobek ketika adanya aktivitas jimak pada malam pertama, tetapi dalam konsep lain mengatakan bahwa seorang wanita yang masih perawan ketika dia belum memiliki buku nikah dan belum pernah melakukan perkawinan. Selain itu ada yang mengatakan bahwa jika ada wanita yang sudah menikah, sudah berjimak, tetapi belum hamil dan melahirkan,maka masih dikatakan perawan. Bermacam-macam konsep perawan di atas menjadi rujukan untuk melakukan pembatalan perkawinan. ${ }^{3}$

Pembatalan perkawinan di dalam UU Republik Indonesia No. 1. Tahun 1974 Tentang Pernikahan, pada BAB IV Batalnya Perkawinan dalam pasal 22-28 dalam permasalahan ketidak perawanan dikaitkan dengan pasal 27 ayat $(2)^{4}$ dan KHI, pada BAB XI Batalnya Perkawinan Pada Pasal 70-76 mengatur tentang pembatalan pernikahan, yang dalam perihal masalah ketidakperawanan dikaitkan dengan $\mathrm{KHI}$ Pasal 72 ayat (2): “ Seorang suami atau isteri dapat mengajukan permohonan pembatalan

\footnotetext{
2 Abdul Rahman Ghozali, Fiqh Munakahat (Jakarta: Kencana, 2012)

3 Rojudin (Hakim PA kota Padangsidimpuan), Wawancara, Pada tanggal 28 Januari 2021.

4 UU RI No. 1 Th. 1974 Tentang Perkawinan dan Kompilasi Hukum Islam (Bandung: Citra Umbara, 2011).
} 
perkawinan apabila pada waktu berlangsungnya perkawinan terjadi penipuan atau salah sangka mengenai diri suami atau istri" ${ }^{5}$

Perceraian pada UU No. 1. tahun 1974, mengenai perceraian tercantum pada BAB VIII berakhirnya suatu Perkawinan, dan dampaknya pada pasal 38-41 dan KHI pada BAB XVI berakhirnya Perkawinan terdapat beberapa pasal, terutama pada pasal 116 ayat (f): "Antara suami istri terus menerus terjadi perselisihan dan pertengkaran dan tidak ada harapan akan hidup rukun lagi dalam rumah tangga". ${ }^{6}$

Pada pasal ini rentan dijadikan sebagai alasan-alasan berakhirnya perkawinan yang disebabkan oleh perselisihan dan pertengkaran dikaitkan dengan masalah keperawanan. Salah satu alasan penyebab perceraian yang menimbulkan perdebatan yaitu antara suami dan isteri sering terjadi keributan dan perselisihan yang bisa di damaikan, yang termuat dalam pasal 39 ayat (2) huruf $\mathrm{f}$ UU Perkawinan No.1 1974 jo. pasal 19 huruf f PP tentang Pelaksanaan UU Perkawinan jo. pasal 116 huruf f Kompilasi Hukum Islam. Pasal ini menjlaskan bahwa ketika didalam perkawinan tidak ada lagi kerukunan dan kedamaian, maka salah satu dari pasangan tersebut bisa mengajukan percereian di pengadilan Agama.

Keributan yang terjadi di dalam perkawinan yang tidak memungkinkan lagi membanguan keluarga yang bahagia dalam pasangan tersebut, istilah ini di dalam ilmu hukum di kenal dengan "Onheelbare Twesspalt" keributan yang muncul menjadi sebab di ajukan percereian tidak hanya dikenal di dalam Undang-undang dan KHI saja, tetapi di dalam Hukum Adatpun perpisahan bisa di akibatkan penganiayaan oleh suami terhadap istri atau sebaliknya, penyiksaan yang terus menerus dilakukan tiada akhir dan tidak akan mungkin untuk mendamaikannya lagi, menyebabkan cacat badan, cacat bathin, penyakit yang tidak bisa di sembuhkan serta timbulnya kebencian antara kedua belah pihak. ${ }^{7}$ Bahwa dikabulkanya perceraian disebabkan alasan di atas yang tidak memiliki tolak ukur dan bersifat

\section{(2)}

${ }^{5}$ Intruksi Presiden R.I. Nomor 1 Tahun 1991 Kompilasi Hukum Islam, Bab XI, Pasal 72 ayat (f)

${ }^{6}$ Intruksi Presiden R.I. Nomor 1 Tahun 1991 Kompilasi Hukum Islam, Bab XI, Pasal 116 ayat

7 Mys, "Onheelbare Tweespalt dalam Doktrin dan Yurisprudensi," hukumonline.com, diakses 30 November 2021, https://hukumonline.com/berita/baca/lt4f7ab5bef40e2/ionheelbaretweespalt-i-dalam-doktrin-dan-yurisprudensi. 
relatif dan non indikator, sehingga memiliki kecenderungan untuk lebih mudah diajukan di depan persidangan.

Berdasarkan uraian di atas, Bahwa dalam BAB XII Hak dan Kewajiban Suami Isteri pada pasal 77 ayat (4) disebutkan bahwa: "Suami isteri wajib memelihara kehormatannya." Selain itu sebuah pernikahan adalah Mitsaqan Ghalizan atau ikatan sangat kuat, pernikahan yang seharusnya dipenuhi dengan sakinah mawaddah warahmah sebagaimana tujuannya. Untuk itu diperlukan kajian guna meluruskan padangan tersebut dengan komprehensif ${ }^{8}$ antara perspektif hukum Islam dan perspektif feminisme.

Pandangan hukum Islam dalam hal hubungan yang terjalin, yang berkaitan dengan boleh atau tidak, halan atau haram, dan sejenisnya yang ada di dalam nash. Dalam Islam dikenal dengan istilah Hukum Islam yang didalamnya mengandung perintah dan larangan Allah, maupun hubungan antar sesama dengan menjelaskan fenomena alam melaluia Al-Qur'an dan hadis. Hukum Islam merupakan aturanaturan yang mengatur perbauatan manusia berdasarkan kebiasaan di masyarakat, dengan harapan bisa membawa ke dalam keadaan yang baik dan aman. ${ }^{9}$

Feminisme merupakan sebuah gerakan yang mengupayakan kesetaraan gender. Aliran-aliran di dalam feminisme memiliki teori-teori yang berbeda tetapi memiliki tujuan yang sama untuk menghilangkan patriarki untuk kesetaraan gender. ${ }^{10}$ Apakah satu-satunya cara untuk membuktikan dan mempertahankan perkawinan hanya dibebankan kepada perempuan, yakni dengan adanya pendarahan saat jimak di malam pertama dan apakah harus menuntut masalah keperawanan. Meskipun,status perawan tersebut adalah satu penghargaan terbesar bagi seorang pria dan bahkan bagi seorang perempuan itu sendiri dalam sebuah kehidupan perkawinan.

Berdasarkan penjelasan dan problematika yang dijelaskan, penulis ingin menulis tentang " Konsen Keperawanan Terhadap Pembatalan Perkawinan

8 "Arti kata komprehensif - Kamus Besar Bahasa Indonesia (KBBI) Online," diakses 30 November 2021, https://kbbi.web.id/komprehensif.

${ }^{9}$ Koko Abdul Kodir, Metodologi Studi Islam (Bandung: Pustaka Setia, 2014) 2001)

10 Nassaruddin Umar, Argumen Kesetaraan Jender Perspektif Al-Qur'an (Jakarta: Paramadina, 
Tinjauan Hukum Islam dan Feminisme". Penelitian ini lebih fokus akan melihat tentang bagaimana konsep perawan dalam perkawinan ditinjau dengan hukum Islam dan Feminisme? Dan yang kedua ingin melihat konsep perawan dapat dijadikan alasan untuk pembatalan perkawinan?

\section{B. Pembahasan dan Konsep Keperawanan Dalam Pernikahan Perspektif Normatif dan Feminisme}

1. Tinjauan Normatif

a. Pernikahan Dalam Hukum Islam

Secara normatif hukum Islam merupakan bagian dari aturan Islam yang memiliki sanksi bagi ummat muslim. Penerapannya bergantung pada tingkat kesadaran masyarakat muslim dalam memahami norma-norma dan aturan hukum Islam yang bersifat normatif. ${ }^{11}$ Selain itu hukum Islam merupakan hukum Tuhan karenanya aturan yang abadi dan berlaku sepanjang zaman. ${ }^{12}$

Islamic Law merupakan aturan-aturan berlandaskan wahyu dari Allah dan sabda Rasul, berkaitan dengan perbuatan mukallaf yang dipahami, yang diakui, diyakini dan di taati berlaku untuk mengikat seluruh umat yang beragama Islam. ${ }^{13}$ Konsep lain hukum Islam merupakan hasil dari penemuan manusia yang bersifat kontekstual bisa berubah. ${ }^{14}$ Hukum Islam menjadi formulasi dari salah satu ajaran hukum Islam. Hukum Islam menjadi unsur normatif dalam penataan hidup masyarakat. Sebagai bahagian dari ajaran hukum Islam maka konsep syari'at Islam juga merupakan norma-norma dalam agama, juga mengatur hubungan hamba dengan sang pencipta, yang disebut dengan ibadah. Diantaranya mengatur juga pada kaidah ibadah yang berkaitan dengan al-ahwalus syakhshiyah atau kajian mengenai hukum pernikahan (munakahat).

Perkawinan yaitu sunatullah yang umum, berlaku untuk semua makhluk, mulai dari hewan, manusia bahkan termasuk tumbuhan sekalipun. Merupakan

11 Tjun Surjaman, Hukum Islam di Indonesia: Pemikiran dan Praktek (Bandung: Remaja Rosdakarya, 1991)

12 Miftahul Huda, Filsafat Hukum Islam Menggali Hakekat, Sumber dan Tujuan Hukum Islam (Ponorogo: STAIN Po Press, 2006)

13 Abdul Halim Barkatullah dan Teguh Prasetyo, Hukum Islam; Menjawab Tantangan Zaman Yang Terus Berkembang (Yogyakarta: Pustaka Pelajar, 2006)

14 Syamsul Anwar, Epistemologi Hukum Islam (Yogyakarta: Penelitian IAIN Sunan Kalijaga Yogyakarta, 2000) 
sebuah cara yang di pilih oleh ciptaan Allah untuk menjadi lebih banyak/berkembang biak untuk melestarikan kehidupan. ${ }^{15}$ Adapun kata nikah (annikâh) digunakan dalam hubungan suami istri dan akibat yang berlaku dalam Islam.

Kata nikah berasal dari نكع dalam bahasa Arab, yang artinya kawin. ${ }^{16}$ Secara etimologi nikah berarti bersenggama atau bercampur. Ali Mugni menurut kitab figh pada umumnya menyebutkan dalam bukunya perkawinan di istilahkan dengan ziwaj dan nikah, yang bermakna dam, yakni menindih, menghimpit dan berkumpul. ${ }^{17}$ Perkawinan dalam KBBI yaitu kawin yang artinya membangun keluarga dengan lawan jenis, selanjutnya hubungan intin/kelamin atau bersetubuh. ${ }^{18}$ Islam menganjurkan pernikahan karna adanya unsur ibadah di dalam peran dan tujuan pernikahan. Menurut hukum Islam, terdapat beberapa pengertian perkawinan, diantaranya: menurut syara' disebutkan bahwa nikah yaitu saling memuaskan antara pria dan wanita, untuk membentuk sebuah rumah tangga yang sejahtera. ${ }^{19}$

Pernikahan dalam hukum Islam yaitu hubungan antara pria dan wanita yang mana sebelumnya di larang, maka setelah menikah di bolehkan. Manusia pada dasarnya dalam kehidupan pernikahan menyebabkan terjadinya perpisahan/perceraian, ketidakseimbangan dalam rumah tangga, sehingga menjadi perhatian yang khusus mengenai penegasan arti pernikahan. Yang demikian bukan hanya masalah jimak saja tetapi jauh dari itu juga pada tujuan adanya akibat hukum dari pernikahan.

Pernikahan itu merupakan suatu akad, maka perlu perjanjian, karena itu nikah juga diartikan dengan mengadakan perjanjian (Mîtsâqan Ghalîzhan) ikatan yang sangat kokoh antara seorang pria dengan mengadakan perjanjian ikatan antara seorang prian dengan wanita untuk melakukan kehidupan suami istri, hidup dalam satu rumah tangga dan meneruskan keturunan sesuai dengan ketentuan syariat 1999)

15 Slamet Abidin dan Aminuddin Aminuddin, Fiqh Munakahat I (Bandung: Pustaka Setia,

16 Rahmat Hakim, Hukum Perkawinan Islam (Bandung: Pustaka Setia, 2000)

17 Ali Mughni, al Misbah al Munir (Kairo: ttp, tt)

${ }^{18}$ Dep Dikbud, Kamus Besar Bahasa Indonesia (Jakarta: Balai Pustaka, 1994)

19 Tihami Tihami dan Sahrani Sahrani, Fikih Munakahat: Kajian Fikih Nikah Lengkap (Jakarta: Rajawali Pers, 2014) 
agama. ${ }^{20}$ Perkawinan (az-zawâj) yang dikemukakan oleh ahli fiqh dan ahli hadis, adalah hubungan antara suami dan istri dengan ikatan hukum Islam, dengan melengkapi syarat dan rukun perkawinan. ${ }^{21}$

Perkawinan dalam Islam mendapatkan perhatian khusus, karena tidak sedikit ayat dalam al-Qur'an yang menyebutkan tentang perkawinan. Kata nikah disebut sebanyak 23 kali yang bermakna berhimpun, dan dengan kata zawaja 80 kali yang bermakna berpasangan. Sehingga dua istilah berhimpun dan berpasangan digunakan untuk menggambarkan hubungan suami istri yang sah. Serta banyak hadits-hadits Nabi yang menyebutkan mengenai anjuran untuk menikah sebagai salah satu sunnah Nabi. ${ }^{22}$ Seperti dalam Surah An-Nur ayat 32 dn surat Ar-Rum ayat 21.

Nabi Muhammad bersabda yang diriwayatkan At-Tirmidzi dari Abu Ayyub $r a$, ia menuturkan bahwa:

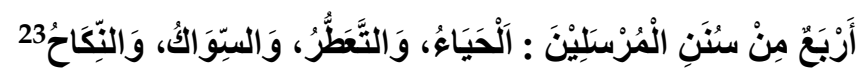

Pernikahan dalam Islam memiliki dimensi permuliaan derajat manusia, hal ini untuk membedakan manusia beriman dengan yang bukan. Pernikahan merupakan penyaluran nafsu syahwat manusia secara sah dan halal. ${ }^{24}$ Menurut Abdurrahman al-Jaziri, dalam bukunya menyebutkan bahwa pernikahan menurut Mazhab Syafii adalah akad yang berisi penjelasan tentang hukum menghalalkan bersenggama, dilengkapi dengan lafadz nikah, tajwij atau kata yang berbeda tapi memiliki makna yang sama dengan kedua kata tersebut. Ataupun nikah adalah suatu akad yang bertanggung jawab atas kebolehan jimak dengan lafadz nikah dan tajwij. ${ }^{25}$

${ }^{20}$ E. Mustofa A.F, Islam Membina Keluarga dan Hukum Perkawinan di Indonesia (Yogyakarta: Kota Kembang, 1987)

${ }^{21}$ Ali Yusuf As-Subki, Figh Keluarga: Pedoman Bekeluarga Dalam Islam (Jakarta: Amzah, 2010)

22 Nurun Najwah, Benarkah Nikah Sirri dibolehkan? Dalam Telaah Ulang Wacana Seksualitas (PSW UIN Sunan Kalijaga Yogyakarta: Depag RI, 2004)

${ }^{23}$ HR. At-Tirmidzi

24 Wirjono Prodjodikoro, Hukum Perkawinan di Indonesia (Bandung: Pionir Jaya, 1986)

${ }^{25}$ Abdurrahman al-Jaziri, al-Figh 'ala al-Mazahib al-Arab'a, Juz IV (Beirut: Dar al-Fikr, tt) 
Dengan pernikahan ini berharap mendapatkan nilai transdental dan sakral untuk mendapatkan tujuan pernikahan yang sejalur dengan syariat Islam. ${ }^{26} \mathrm{Hukum}$ perkawinan, yaitu aturan-aturan yang mengatur hubungan sesama manusia, yang berkaitan dengan hak dan kewajiban dan juga kebutuhan biologis manusia.

Perkawinan adalah sunnah dari Allah dan hukum dasarnya adalah mubah tergantung dari kondisinya, karena hukum perkawinan ada 5 tergantung keadaan. ${ }^{27}$ Salah satu Ibadah yang di ajurkan untuk umat Islam adalah menikah, karena banyak keunggulan di dalamnya, selain itu juga merupakan fitrah manusia yang membutuhkan pasangan, juga merupakan sarana paling mulia dalam menjaga keturunan dan hubungan antar sesama manusia. Bahkan suatu ketika nabi pernah menegur pemuda yang tidak ingin menikah dan menghabiskan waktu untuk beribadah kepada Allah, karena mebujang tidaklah dio syariatkan di dalam Islam.

Perkawinan bukan hanya anjuran dari nabi, tetapi lebih jauh dari itu ada hikmah yang terkandung di dalamnya. Di antaranya mata akan terjaga dari melihat yang tidak baik, dan yang terpenting adalah menjaga kehormatan diri dari kerusakan seksual. Islam sangat memberikan perhatian dan tuntunan agar bisa mencapai derajat keluarga yang SAMAWA dalam perkawinan. Karena dengan menjalankan pernikahan maka terpenuhilah separoh dari agama seseorang.

Dengan demikian pernikahan merupakan akad yang mengubah hukum haram antara pria dan wanita melakukan hubungan badan/bersetubuh (jima') menjadi boleh dan merupakan tujuan utama pernikahan, yakni untuk mengambil manfaat atau bersenang-senang dan mendapatkan keturunan. Pernikahan memiliki tujuan untuk memuliakan manusia dalam menyalurkan hasratnya sebagai makhluk biologis dengan ikatan yang kuat yaitu ijab dan qabul.

\section{b. Keperawanan Menurut Padangan Hukum Islam}

Keperawanan merupakan sesuatu yang sangat berharga bagi seorang wanita. Karenanya, menjaga keperawanan adalah keniscayaan, dan tak bisa ditawar lagi. Islam menganjurkan disalah satu dari kriteria untuk memilih istri adalah untuk

${ }^{26}$ M. Anshary, Hukum Perkawinan di Indonesi: Masalah-Masalah Krusial (Yogyakarta: Pustaka Pelajar, 2015).

27 Tihami dan Sahrani, Fikih Munakahat: Kajian Fikih Nikah Lengkap 
menikahi wanita perawan, karena perawan lebih dicintai dan menyayangi suaminya dari pada janda. Ini merupakan karakter yang ditanamkan pada diri manusia. Bahkan dalam salah satu hadis nabi, beliau menyuruh/menganjurkan untuk menikah dengan wanita yang masih perawan.

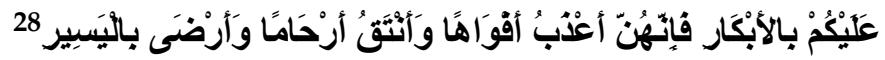

Dari Jabir ra, Rasulullah bersabda:

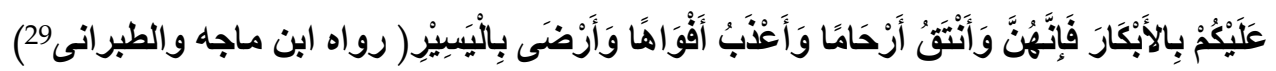

Rasulullah menganjurkan menikahi perawan karena memiliki kelebihan, seperti yang di katakan oleh Abu Hamid al Gazali: perawan lebih saying kepada suami, suami nyaman kepadanya, karena belum pernah disentuh dan ikhlas menerima suami,karena belum ada bandingannya. Sedangkan kelemahan janda, pengalaman yang dia miliki sebelumnya, mayoritas tidak bisa menerima ketika ada perbedaan dengan suami sebelumnya. ${ }^{30}$ Sedangkan wnaita yang hilang perawan karena jatuh, haid deras, luka dan perawan tua disebut sebagai perawan. Sama halnya nikah yang di fasakh dengan wanita yang sudah menikah tapi di tinggal oleh suami sebelum adanya jimak atau kelamin suaminya terpotong, maka wanita itu termasuk perawan juga. ${ }^{31}$

Perawan yang telah hilang adalah ketika wanita yang hilang perawannya disebabkan oleh perkawinan dan bukan yang lainnya. Ini pendapat dari hanafiyah. Kemudian wanita yang jatuh, haid kuat, luka, perawan tua tergolong perawan baik secara hukum maupun pada hakikatnya. Sedangkan Malikiyah menyebutkan wanita perawan adalah yang belum bersenggama. ${ }^{32}$

Imam al Haramain al Juwaini dalam kitab Nihayah al Mathlab fi Dirayah al Madzhab. Perawan adalah selaput darah. Wanita yang masih perawan ketika selaput darahnya belum robek. Pendapat ini menyebutkan bahwa perawan bisa hilang karena dua sebab, yaitu hilang karena jimak,, 33 dan hilangnya perawan karena jatuh,

\footnotetext{
28 H.R. Baihaqi

${ }^{29}$ HR. Ibnu Majah dan Ath-Thabarani

30 Syaikh Fuad Shalih, Untukmu yang Akan Menikah E Telah Menikah (Jakarta: Pustaka AlKautsar, 2005)

31 al-Jaziri, al-Figh 'ala al-Mazahib al-Arab'a, Juz IV.

32 Abdurrahman al-jaziri Al-Mausuu'ah al-Fiqhiyyah VIII/178)

33 Imam al-Haramain al-Juwaini, Nihayah al-Mathlab fi Dirayah al-Madzhab, tahqiq, Abdul Azhim Mahmud ad-Dib, cet ke-1, juz, 12 (Beirut: Dar al-Minhaj, 2007)
} 
memasukkan jari kedalamnya, atau karena terlalu lama senidir. Maka imam Al Haramaian Al Juwaini mengemukakan dua pendapat : pertama: masuk dalam kategori tidak perawan, karena sudah hilang keperawanannya. Kedua : masuk kategori perawan karena pada faktanya tidak pernah melakukan hubungan intim dengan pria.

Sendainya keperawanan hilang karea melakukan lompatan, masukkan jari lama sendiri/melajang, maka kondisi ini ada dua pendapat. Pendapat pertama: dimasukkan kedalam kategori janda. Pendapat kedua: masih perawan karena belum melakukan hubungan intin dengan pria. ${ }^{34}$

Dengan demikian, konsep keperawanan dalam hukum Islam merupakan konsep terhadap wanita yang belum pernah sama sekali melakukan hubungan intim baik zina maupun halal. Hal ini juga berarti tidak mengharuskan bahwa perempuan harus memiliki hymen atau selaput dara yang utuh dalam konteks adanya darah ketika berhubungan. Perawan dalam Islam menyebutkan dalam hal ini, konsep perawan bukan dilihat dari selaput dara tetapi konsep diri perempuan itu sendiri pernah atau tidak melakukan hubungan badan, selama belum pernah melakukan hubungan badan dalam halal maupun haram maka tetap disebut perawan.

Berdasarkan hal ini pula bukan sesuatu yang harus dipermasalahkan dalam pernikahan meskipun perawan memiliki nilai yang lebih diistimewakan dalam memilih pasangan hidup (pernikahan). Perawan dalam konteks ini menekankan bahwa perempuan yang perawan berarti perempuan yang menjaga dirinya dari sesuatu yang merusak kehormatannya (zina) dan tidak pernah melakukan hubungan badan dalam hal apapun. Sehingga apabila perempuan tersebut benar tidak pernah melakukan hubungan badan maka tidak ada hak atau hukuman yang dapat dituduhkan kepadanya bahwa perempuan tersebut bukan perawan dan berhak atas pernikahan yang seharusnya dapat memuliakannya.

\section{Tinjauan Feminisme}

a. Pernikahan Dalam Padangan Feminisme

Perkembangan isu gender di indonesia sangat signifikan, hak ini dipengaruhi oleh karya dari feminis Muslim di berbagai negara Islam, baik itu

34 al-Juwaini 
berupa tulisan, budaya bahkan oral di kalangan pemimpi Islam. Bahkan tuntutan dari feminis membuahkan hasil, sampai dengan kesetaraan gender dalam institusi keluarga. Dengan demikian lahirlah bermacam-macam pandangan terhadap institusi keluarga, misalnya pandangan terhadap institusi keluarga sebagai musuh yang harus dilenyapkan. ${ }^{35}$

Feminisme memandang pernikahan yakni sebagai sebuah keluarga dianggap sumber dari ketimpangan sosial yang ada, hal yang mendasar masalah hak dan kewajiban berbeda antara suami dan istri. halam hal ini, memandang bahwa keluarga adalah patriarki sebagai sumber untuk mencapai masyarakat yang berkelas. Pendapat kaum komunis maxris menyebutkan bahwa kaum wanita adalah privae property bagi suaminya. Bahkan jauh dari itu ada pendapat yang mengatakan bahwa keluarga merupakan lembaga formal yang menindas hak wanita. ${ }^{36}$

Ritzer dan Goodman mengatakan bahwa didalam masyarakat akan terdapat dua lembaga perkawinan, pertama: perkawinan yang mana suami memiliki keyakinan bahwa adanya beban tanggung jawab, walaupun nanti adanya secara norma mendapatkan wewenng, kebebasan, pemeliharaan, pelayanan dan seksual dari istri. Kedua: perkawinan dimana wanita meyakini bahwa dia berfungsi sebagai pemenuhan, walaupun dari normatif mengalami ketidak berdayaan dan ketergantungan, dan menganggap sebuah kewajiban untuk melayani, kasih sayang, dan seksual kepada suaminya, walaupun secara bertahap mengurahi kebebasan seperti sebelum dia menikah. ${ }^{37}$

Berdasarkan hal ini pernikahan dalam pandangan feminisme merupakan bentuk patriakhi yang bersifat diskriminasi internal maupun eksternal terhadap diri seorang perempuan. Bahwa dalam pernikahan perempuan dipandang sebagai pihak kedua atau bawahan yang berada dibawah seorang laki-laki, adapun tujuan feminisme merupakan gerakan yang ingin mensejajarkan antara wanita dan pria dalam suatu kedudukan baik ekonomi, sosial dan sebagainya. Pernikahan dalam

35 Jamhari Jamhari, Citra Perempuan dalam Islam Pandangan ORMAS Keagamaan (Jakarta: Gramedia, 2003)

36 Siti Muslikhati, Feminisme dan Pemberdayaan Perempuan dalam Timbangan Islam (Jakarta: Gema Insani, 2004)

${ }^{37}$ George Ritzer dan Douglas J. Goodman, Modern Sociological Theory, 6th Edition (Jakarta: Prenada Media, 2003) 
pandangan feminisme membatasi ruang gerak wanita untuk mendapatkan hak dan kewajiban yang berbeda dengan pria, artinya wanita terbatas ruang geraknya dalam beraktifitas untuk bersaing dengan lawan jenisnya.

b. Keperawanan Menurut Feminisme

Perawan merupakan sebuah simbol bagi seorang wanita, jika wanita bisa menjaganya, kemudian perawan tersebut hanya untuk suami setelah mereka menikah, maka wanita tersebut akan dikatakan baik, sebaliknya apabila wanita tersebut sudah tidak perawan lagi, dan ketidak perawannya itu dia berikan kepada suaminya, maka dia dikatakan sebagai wanita yang tidak baik.

Harga diri tertinggi dari seorang wanita adalah keperawanan yang dimiliki, karena keperawanan tidak bisa di hargai dengan materi. Keperawanan juga merupakan komoditas yang dapat di bicarakan untuk mengeluarkan wanita dari persoalan hidup. Oleh karena itu seorang wanita berhak untuk memberikan kepada siapapun yang dia inginkan tanpa ada tekanan dari siapapun.

Sebuah ungkapan yang di katakan oleh Millet bahwa masyarakat patrialkar, bahwa pria mendapatkan peran sebagai ambisius, pengfhargaan dan kepentingan sedangka wanita hanya sebagai pelayan dan untuk mengasuh anak. Hal tersebutlkah yang memunculkan adanya perbedaan gender dan melahirkan ketidakadilan bagi wanita. 3839

Pendapat dari Feminisme Radikal bahwa yang menjadi penyebab penindasan terhadap wanita adalah bersumber dari pria dan ideologi patriarkinya. Juga sebagai penguasa fisik wanita adalah pria, misal hubungan seksual adalah penindasan terhadap fisik wanita. Hal tersebut sesuai yang di sebutkan bahwa feminisme radikal bergerak melalui pemahaman yang menekankan bahwa seks atau gender di bangun dari ideologi patriarti, merupakan penyebab utama penindasan terhadap wanita. ${ }^{40}$

Dengan demikian perawan menurut feminisme pada dasarnya sebagai unsur yang utama dalam diri seorang perempuan, akan tetapi akibat sistem

\footnotetext{
38 M. Fakih, Analisis gender dan transformasi sosial, (Yogyakarta: Pustaka Pelajar.2013)

${ }^{39}$ M. Fakih, Analisis gender dan transformasi sosial (Yogyakarta: Pustaka Pelajar, 2013)

40 R P Tong dan Penerjemah A.P Prabasmara, Feminist thought: Pengantar paling komprehensif kepada aliran utama pemikiran feminis (Yogyakarta: Jalasutra, 2006)
} 
patriarki tersebut perawan sebagai suatu konsep yang mengubah pandangan perempuan dari bentuk penghargaan terhadap diri perempuan menjadi konsep yang digunakan untuk melawan bias gender atau diskriminasi akibat penindasan yang terjadi terhadap fisik perempuan. Perawan dalam hal ini bukan lagi citra yang dimiliki perempuan tetapi menjadi perlawanan fisik terhadap lawan jenisnya. Konsep perawan menurut feminisme adalah wilayah privasi. Artinya bukan lagi berbicara bentuk selaput dara atau hymen secara fisik, akan tetapi secara non-fisik atau mental yang menjadikan perempuan lebih berhak atas dirinya dan tanpa adanya interferensi dari pihak lain atas privasi diri perempuan tersebut. Dengan demikian konsep keperawanan dalam perkawinan menurut hukum Islam dan feminisme sebagai berikut:

\begin{tabular}{|c|c|c|}
\hline Perihal & Hukum Islam & Feminisme \\
\hline $\begin{array}{l}\text { 1. } \text { Konsep } \\
\text { Pernikahan }\end{array}$ & $\begin{array}{l}\text { Perkawinan } \\
\text { merupakan akad yang } \\
\text { mengubah hukum } \\
\text { haram antara pria dan } \\
\text { wanita melakukan } \\
\text { hubungan badan atau } \\
\text { bersetubuh (jima') } \\
\text { menjadi boleh dan } \\
\text { merupakan tujuan } \\
\text { utama pernikahan, } \\
\text { yakni untuk } \\
\text { mengambil manfaat } \\
\text { atau bersenang-senang } \\
\text { dan mendapatkan } \\
\text { keturunan. }\end{array}$ & $\begin{array}{l}\text { Pernikahan dalam pandangan } \\
\text { feminisme merupakan bentuk } \\
\text { patriakhi yang bersifat } \\
\text { diskriminasi internal maupun } \\
\text { eksternal terhadap diri seorang } \\
\text { perempuan. }\end{array}$ \\
\hline Keperawanan & $\begin{array}{lr}\text { Konsep } & \text { perawan } \\
\text { dalam } & \text { Islam } \\
\text { menyebutkan } & \text { konsep }\end{array}$ & $\begin{array}{l}\text { Konsep perawan menurut } \\
\text { feminisme adalah wilayah } \\
\text { privasi. Artinya bukan lagi }\end{array}$ \\
\hline
\end{tabular}




\begin{tabular}{|c|c|c|}
\hline & $\begin{array}{l}\text { perawan bukan dilihat } \\
\text { dari selaput dara tetapi } \\
\text { konsep diri perempuan } \\
\text { itu sendiri pernah atau } \\
\text { tidak melakukan } \\
\text { hubungan badan, } \\
\text { selama belum pernah } \\
\text { melakukan hubungan } \\
\text { badan dalam halal } \\
\text { maupun haram maka } \\
\text { tetap disebut perawan. }\end{array}$ & $\begin{array}{l}\text { berbicara bentuk selaput dara } \\
\text { atau hymen secara fisik, akan } \\
\text { tetapi secara non-fisik atau } \\
\text { mental yang menjadikan } \\
\text { perempuan lebih berhak atas } \\
\text { dirinya dan tanpa adanya } \\
\text { interferensi dari pihak lain atas } \\
\text { privasi diri perempuan tersebut. }\end{array}$ \\
\hline Kesimpulan & $\begin{array}{l}\begin{array}{l}\text { Sebagaimana } \\
\text { pernikahan } \\
\text { mendapatkan } \\
\text { keturunan, } \\
\text { adalah }\end{array} \\
\text { aktualisasi } \\
\text { actualization) }\end{array}$ & $\begin{array}{l}\text { Feminisme sebagai gerakan } \\
\text { pembebasan dari bentuk } \\
\text { diskriminasi dan patriarkhi } \\
\text { memandang pernikahan sebagai } \\
\text { lembaga tertinggi yang } \\
\text { melakukan penindasan terhadap } \\
\text { perempuan, baik dari segi fisik } \\
\text { termasuk permasalahan } \\
\text { keperawan, segi ekonomi, } \\
\text { hukum, dan sebagainya. Yang } \\
\text { mana pada tujuannya gerakan } \\
\text { ini ingin sejajar dengan lawan } \\
\text { jenisnya dan gerakan untuk } \\
\text { membela kaum perempuan dari } \\
\text { segala unsur penindasan baik } \\
\text { fisik dan mental pada } \\
\text { perempuan. Artinya pernikahan } \\
\text { dan keperawanan adalah privasi } \\
\text { seorang perempuan dalam }\end{array}$ \\
\hline
\end{tabular}




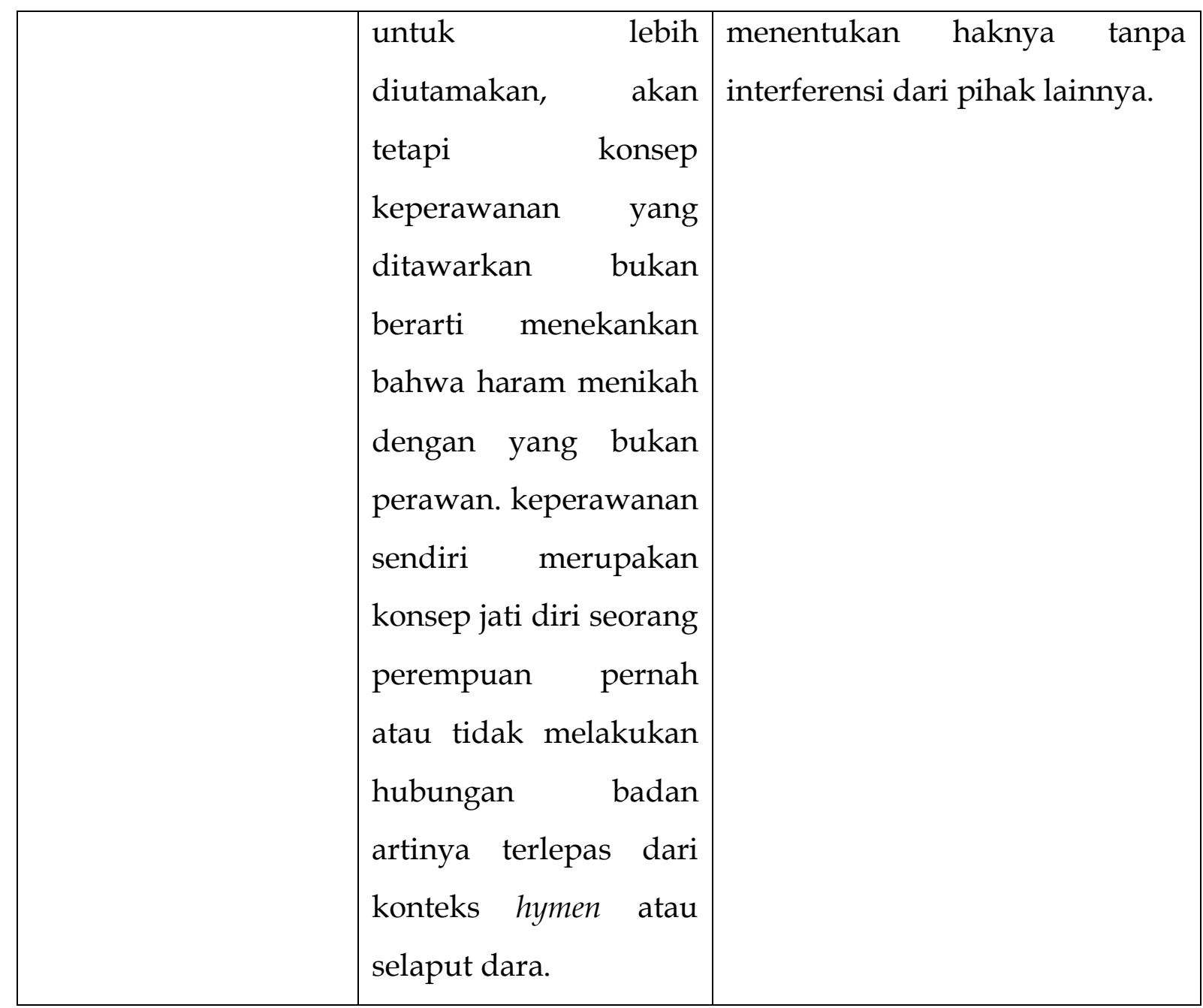

Hukum Islam secara normatif merupakan aturan Islam yang memiliki sanksi kemasyarakatan. Pelaksanaannya tergantung pada kesadaran masyarakat mengenai norma-norma hukum Islam tersebut. Bahwa dalam hukum Islam perkawinan memiliki keutamaan sebagaimana yang tercantum dalam al-Qur'an dan hadits bahwa pernikahan merupakan permuliaan derajat manusia sebagai makhluk biologis dengan jalan yang di syari'ah yang diikuti dengan konsep bahwa syari'ah itu dari Allah dan tidak memperturutkan keinginan hawa nafsu.

Dengan pernikahan yang pada dasarnya memiliki dimensi keutamaan dalam mewujudkannya salah satunya ialah keutamaan menikah dengan gadis/perawan, namun bukan berarti menjadi dasar penghukuman atas hal-hal yang kompleks, keperawanan tolak ukurnya dalam hukum Islam hanya pada tidak pernahnya melakukan hubungan badan tanpa ada identifikasi sebagaimana yang berkembang pada konsep pemikiran di masyarakat yakni harus adanya 
pendarahan. Hymen atau bagian vital seorang perempuan memiliki ukuran yang berbeda.

Dalam buku yang ditulis oleh Neng Dara Afifah, bahwa menurutnya keperawanan dalam Islam menjadi perbincangan karena tiga hal, yaitu: status perempuan yang sudah kawin atau janda, usaha menghindari praktik hubungan seksual diluar nikah (zina), dan sebagai konstruksi atau harga bagi seorang perempuan dalam perspektif masyarakat patriarkhis. Terlihat bahwa konsep tersebut menjadikan konsep perawan adalah konsep yang dibentuk oleh konstruksi nilai dari masyarakat patriarkat yang tujuannya sebagai pengutamaan laki-laki dan pengecilan terhadap diri perempuan dengan hanya melihat selapis tipis selaput dara tanpa melihat kepribadian, pemikiran, keilmuan, keterampilan, dan hal lain yang mencerminkan sisi kemanusiaan seorang perempuan secara keseluruhan.

Potret demikian sejalan dan nyata yang terjadi pada pria pada lingkungan masyarakat, tentu hal ini sudah tidak sesuai lagi dengan ketentuan hukum Islam yang sejatinya lebih mengutamakan sisi sebagai makhluk biologis dengan memperturutkan hawa nafsu (insting primitif) hanya mencari kepuasan tanpa memahami kembali sisi sebagai manusia yang menjalankan perintah Allah dan Rasulullah bahwa menikah memiliki tujuan sebagai jalan untuk memuliakan manusia.

Penulis sendiri pernah mendengar secara langsung dalam salah satu pernikahan, bahwa seorang perempuan sebelum melakukan malam pertama dengan rasa khawatir yang dirasakan dan rasa was-was karena stigma yang berkembang ini, dengan pemikiran tersebut perempuan tersebut melukai dirinya sendiri dengan menyiapkan beberapa tetes darah untuk dapat melewati malam pertama dengan adanya darah perawan.

Hal tersebut selaras pula dengan kisah yang digambarkan Fatima Mernissi yang mengatakan bahwa di Maroko banyak perempuan yang melakukan sebuah tipuan keperawanan dengan cara menggunakan percikan darah ayam yang dilekatkan ke celana dalam sprei perempua. Lalu, bercak darah tersebut diperlihatkan kepada para undangan untuk membuktikan bahwa pengantin perempuan tersebut masih perempuan. 
Dengan demikian, aturan hukum Islam yang sejatinya memberikan kesan permuliaan derajat manusia sebagai makhluk biologis dengan jalan ijab dan kabul menjadi wadah pemuasan nafsu belaka dengan stigma perempuan harus membuktikan kesuciannya dengan adanya darah perawan. Mitos ini lebih diakui oleh sebagian masyarakat tanpa memandang keutamaan nilai syari'ah menikah serta norma-norma yang harus dijaga oleh perempuan. Dalam Islam perempuan di perintah untuk menutup aurat untuk menjaga kemuliaannya, perempuan dilarang memakai wangi-wangian dan bahkan suara perempuan adalah aurat baginya, perempuan juga ketika berpergian harus diantar oleh muhrimnya yang demikian ini adalah keutamaan yang diberikan Islam untuk memuliakan seorang perempuan.

Perempuan memiliki keutamaan yang lebih istimewa dibanding dengan laki-laki, keutamaan inilah yang menjadikan ruang gerak perempuan terbatas sehingga mentalitas perempuan disandingkan dengan mahkota kesuciannya, akibatnya menjadi bergantung dengan laki-laki. Psikis dan fisik perempuan yang sering menjadi tolak ukur penilaian oleh masyarakat pada dirinya. Apabila perempuan itu perawan maka dia perempuan baik-baik, dan apabila tidak perawan maka dianggap sebagai perempuan yang buruk. Adapun perawan adalah hymen atau selaput daranya dibuktikan dengan adanya darah perawan.

Bentuk intimidasi dan diskriminasi terhadap perempuan adalah dengan stigmatisasi tuduhan bahwa istri tidak perawan. Hal tersebut menjadi sangat mudah bagi laki-laki untuk melakukan pembatalan pernikahan. Dengan hal ini, dalam hukum Islam dan feminisme merupakan hal yang tidak memiliki pondasi atau tolak ukur atas penilaian keperawanan dalam sisi harus adanya pendararan, artinya tidak ada konsep perawan yang ditawarkan demikian. Namun kedua perspektif tersebut menunjukkan bahwa konsep perawan adalah wanita yang tidak pernah berbuat hubungan intim baik secara halal maupun haram (zina) dengan laki-laki manapun sebelum pernikahan, terlepas dengan konsep fisik bagian vital seorang perempuan, karena hal tersebut adalah wilayah privasi yang setiap perempuan memiliki perbedaan baik dari segi bentuk dan histori (kejadian yang menyebabkan lukanya selaput dara, akibat jatuh, pendarahan haid yang deras, atau kejadian yang didukung medis lainnya). Adapun dalam pernikahan tujuan utama yang dinilai 
dalam ketentuan pasangan ialah agamanya, kecantikannya, kedudukannya, serta kekayaannya, dan masih banyak yang dapat dinilai dari seorang perempuan, seperti perilaku. Hal ini menunjukkan bahwa baik pria dan wanita dalam pernikahan yang utama adalah perasaan cinta dan kasih sayang yang dapat membangun kehidupan rumah tangga sebagaimana tujuan hukum Islam.

\section{Analisis Tinjauan Konsep Keperawanan Sebagai Alasan Untuk Pembatalan Pernikahan}

Keperawanan sebagai alasan pembatalan pernikahan menyangkut permasalahan dalam bentuk perceraian, pembatalan pernikahan dan putusnya pernikahan. Dalam hal ini penulis sesuai dengan konsep hukum Islam menggunakan fatwa dalam menjawab persoalan tersebut. Adapun salah satu fatwa yang penulis gunakan ialah menurut Majmu' Fatawa Asy-Syaikh Bin Baz telah menjawab dalam sebuah pertanyaan bahwa ketika pria mengawini wanita kemudian telah lewat malam pertama, kemudian baru mengetahui bahwa istirnya tidak perawan,dan apa yang harus dilakukan?, dalam Fataawa al-Jaami 'al-Kabir disebutkan yang telah diterjemahkan bahwa:

Beberapa penyebab hilangnya keperawanan bisa saja bukan karena zina, maka wajib berprasangka baik kepada istri. Namun, bisa saja dahulu memang dia pernah berzina dan telah bertaubat, lalu sudah kelihatan kebiakannya, maka dosa yang lalu tidak ada hubungan dengan suaminya. Bisa jadi perawan itu hilang karea haid yang berat. ${ }^{41}$

Penjelasan dari ulama bahwa keperawanan dapat hilang ketika wanita itu melompat secara kuat dan dengan tenaga yang kuat. Jadi, perawan tidak semuanya hilang karena perzinaan. Apabila istri memberitahukan bahwa perawannya hilang bukan karena zina, maka seorang suami tidak perlu menghawatirkannya.

Seumpama dahulu istri pernah berzina dan telah bertaubat, karena dahulu dia merasa bodh dan tidak tahu sekarang sudah bertaubat, maka hal ini juga

41 “Memperbincangkan Keperawanan, Ketidakadilan Gender - Universitas Muhammadiyah Yogyakarta," diakses 30 November 2021, https://www.umy.ac.id/memperbincangkankeperawanan-ketidakadilan-gender. 
sseharusnya tidak dijadikan masalah oleh suami. Dan tidak boleh pula suami menyebar aib istri, suami berkewajiban menyimpan aib tersebut. Ketika istri tersebut melihatkan kebaikan dan kejujuran maka hendaklah suami mempertahankan istri tersebut. Tapi sebaliknya jika tidak ada kelihatan kebaikan maka silahkan di ceraikan tanpa membuka aibnya supaya tidak terjadi fitnah. ${ }^{42}$

Keperawan sebagai alasan pembatalan pernikahan dalam konsep pernikahan yang berakhir akibat hilangnya keperawanan seorang perempuan karena zina maka penulis dalam hal ini sepakat dengan fatwa diatas karena berhubungan dengan tujuan utama pernikahan adalah membangun keluarga dan menciptakan keturunan, bahwa benar Islam mengajurkan untuk menikahi perawan, akan tetapi bila yang terjadi apabila perempuan tersebut telah berupaya memperbaiki kehidupannya dan mengakui kesalahannya maka selayaknya laki-laki atau suami tersebut dapat menerima dan memberi kesempatan untuk berubah. Sehingga perlu menurut penulis, dalam pernikahan itu unsur kasih sayang dan cinta yang mendalam serta keimanan yang dimiliki baik oleh pria maupun wanita dalam memilih untuk melakukan pernikahan.

Menggauli istri diperlukan interaksi yang penuh dengan rasa kasih sayang. Hal ini merupakan cara sederhana dalam memperbaiki istri, maka perlu meluruskan tujuan pernikahan sebelum melakukan ijab kabul. Allah telah menyebutkan dalam al-Qur'an surah Ar-Rum ayat 21:

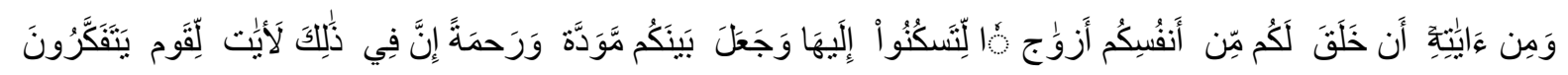

Ayat ini mengajarkan bahwa seorang laki-laki dan perempuan telah Allah tentukan jodohnya sebagai bentuk keimanan dan untuk menambah ketaqwaan pada diri seseorang. Allah menunjukkan tanda kekuasaan-Nya dengan menciptakan istri dari jenis laki-laki itu sendiri, hal ini agar suami merasa nyaman. Dan Allah memberikan rasa kasih dan sayang diantara keduanya. Dengan demikian terdapat tanda-tanda bagi kaum yang berpikir.

Berdasarkan hal lain terkait analisis konsep keperawanan sebagai alasan untuk pembatalan perkawinan, dalam hukum perkawinan di Indonesia memiliki

42 Ammi Nur Baits, "Ternyata Istriku Tidak Perawan," Konsultasi Agama Dan Tanya Jawab Pendidikan Islam (blog), diakses 30 November 2021, https://konsultasisyariah.com/22591-ternyataistriku-tidak-perawan.html. 
prinsip atau asas-asas yang tercantum dalam PP RI Nomor. 9. Tahun 1975 Tentang Pelaksanaan UU Nomor. 1. Tahun 1974 tentang Perkawinan setidaknya ada beberapa prinsip atau asas secara general, salah satu diantaranya adalah mempersukar perceraian. Sebuah perceraian baru bisa dilakukan apabila ada alasan yang kuat, dan dilakukan dalam persidangan, ketika hakim dan juru damai tidak bisa menyatukan kedua belah pihak. ${ }^{43}$ Prinsip atau asas ini ditegaskan pula dalam Pasal 39 UU Nomor 1 Tahun 1974 tentang Perkawinan, pasal tersebut merumuskan bahwa percereaian yang diakui adalah yang dilakukan dalam persidangan dan dengan adanya alasan yang kuat, kemudian juga tidak akan mendapatkan kata sepakat untuk bersatu. ${ }^{44}$

Pembatalan pernikahan yang dilakukan oleh Hakim dengan sebab salah satu dari mereka merasa tertipu terhadap hal-hal yang belum diketahui sebelum berlangsungnya pernikahan. Pelaksanaan fasakh dengan cara pihak yang merasa menemui cela prinsipil tersebut atau merasa tertipu dalam perkawinan itu mengajukan permintaan pembatalan pernikahan kepada Hakim. ${ }^{45}$

Fasakh yang menjadi penyebabnya minimal ada dua keadaan, pertama karena rukun dan syarat yang tidak cuku dan kedua karena tidak mungkin lagi rumah tangga tersebut untuk di lanjutkan. ${ }^{46}$

Pada analisis ini penulis meninjau konsep keperawanan sebagai alasan untuk pembatalan pernikahan pada sebuah putusan yakni bahwa pada satu sisi pembatalan pernikahan tersebut merupakan keputusan yang adil namun pada sisi lain melanggar prinsip imparsial. Penulis meninjau konsep keperawanan sebagai alasan pembatalan pernikahan tersebut hanya sekedar tuntutan hukum yang harus ditegakkan guna untuk memutuskan status hukum. Padahal lebih dari hal itu, terkait akibat putusnya perkawinan bukan hanya persoalan hukum formil yang akan diterima oleh perempuan tersebut tetapi juga persoalan hukum sosial.

\footnotetext{
43 Undang-undang perkawinan No 1 Tahun 1974 (Bandung: Citra Umbara, 2011)

44 Undang-undang perkawinan No 1 Tahun 1974

45 Sajuti Thalib, Hukum Kekeluargaan Indonesia, Cet- 5, (Jakarta: UI Press, 1986)

${ }^{46}$ Amir Syarifuddin, Hukum perkawinan Islam di Indonesia, Antara Figh Munakahat dan Undangundang Perkawinan (Jakarta: Kencana, 2006)
} 
Bagaimana status hukum perempuan tersebut dengan latarbelakang perceraian dengan sebab atau alasan yang didalilkan dengan persoalan tersebut.

Penulis merasa tidak cukup adil atas tidak adanya tolak ukur yang ilmiah dan logis terkait permasalahan keperawanan karena tidak ada pembuktian yang akurat untuk mendalilkan persoalan tersebut ke dalam ranah hukum. Hanya karena pemenuhan asas untuk dapat menjatuhkan perceraian yakni terjadi penipuan atau salah sangka mengenai diri suami atau istri serta pereselisihan yang tidak ada jalan damai. Dalam hal ini, penulis melihat bahwa perselisihan dan pertengkaran tidak terjadi antara kedua belah pihak, melainkan hanya upaya perceraian yang didatangkan dari pihak pria, adapun pihak wanita dalam hal ini adalah pihak yang dirugikan karena dalil-dalil alasan perceraian hanya persoalan keperawanan.

Berdasarkan hal ini, benar apabila Pengadilan wajib berusaha mendamaikan para pihak. Upaya melakukan perdamaian lewat mediasi tetapi tidak berhasil, maka seorang hakim akan dituntut untuk teliti dalam menemukan alasan untuk menjatuhkan keputusan mereka bercerai. Dengan ini pasangan tersebut harus memberikan alasan yang cukup, yang menjelaskan mereka tidak bisa bersatu lagi. Sesuai dengan PP RI nomor. 9. Tahun 1975 tetang Pelaksanaan UU No.1. Tahun 1974 tentang perkawinan pasal 22 ayat (2) jo Kompilasi Hukum Islam Pasal 134 yang berbunyi: "gugatan perceraian karena alasan tersebut (Pasal 19 huruf f jo pasal 116 huruf f) dapat diterima apabila telah cukup jelas bagi Pengadilan mengenai sebabsebab perselisihan dan pertengkaran itu dan setelah mendengar pihak keluarga serta orang-orang yang dekat dengan suami-isteri itu".

Namun, Hakim juga memiliki kewenangan dalam melakukan pertimbangan hukum yang ideal termasuk menempuh jalur yang diatur dalam pasal 154 ayat (1) HIR, Pasal 215 Rv, dalam ketentuannya menyebutkan dua cara pengangkatan ahli, dalam bentuk hak hakim secara Ex Officio, yang mana seorang hakim bisa menunjuk saksi ahli ketika diperlukan tentu dengan persetujuan para pihak. Meskipun hanya sebatas menunjuk saksi ahli. Dengan ketentuan orang yang ditunjuk benar-benar 
memenuhi syarat sebagai ahli dengan spesialisasi yang dikuasainya dalam bidang perkara yang disengketakan. ${ }^{47}$

Persengketaan dalam perkara demikian, dengan dalil masalah keperawanan seharusnya hakim mendatangkan saksi ahli dari kesehatan untuk membuktikan dan membantah perkara yang demikian. Jadi, dalam hal ini hakim seharusnya perlu untuk mendatangkan saksi ahli untuk meluruskan permasalahan kompleks yang pada hakikatnya tidak memiliki tolak ukur, sehingga asas mempersulit perceraian dapat diterapkan meskipun dalam hal lain perselisihan terjadi sehingga tidak mencapai tujuan pernikahan lagi, namun dengan upaya ini dapat dicegah ataupun dipersulit dengan mendatangkan saksi ahli yang mampu menjawab persoalan dan meluruskan hal tersebut.

Berdasarkan hal itu pula, penulis menjelaskan bahwa perawan adalah kehormatan seorang wanita tang tak ternilai harganya, dan wajib hukumnya untuk menjaganya. Islam menganjurkan disalah satu dari kriteria untuk memilih istri adalah untuk menikahi perawan, karena lebih mencintai dan menyanyangi suaminya. Bahkan dalam salah satu sabdanya Rasulullah menganjurkan untuk menikah dengan wanita perawan. "Hendaklah kalian menikah dengan gadis karena mereka lebih segar baunya, lebih banyak anaknya (subur), dan lebih rela dengan yang sedikit" (H.R. Baihaqi).

Mengapa keperawanan menjadi alasan-alasan dalam pembatalan pernikahan menurut penulis bahwa adanya pandangan yang sudah sejak lama tertanam dalam adat istiadat masyarakat terkait konsep keperawanan, dan pada umumnya yang sering terjadi bahwa seorang perempuan yang dikatakan perawan adalah perempuan yang selaput darahnya berdarah ketika malam pertama dilakukan dalam perkawinan yang sah.

Selain itu aturan yang dijadikan sebagai dasar untuk menimbulkan alasanalasan pembatalan pernikahan seperti penipuan dan salah sangka dalam pernikahan, dan juga perselisihan. Sehingga perlu keadilan dalam memutuskan perkara pemutusan pernikahan ini dengan alasan yang ilmiah dan berdasarkan teori

47 M.Yahya Harahap, Hukum Acara Perdata Tentang Gugatan, Persidangan, Penyitaan, Pembuktian, dan Putusan Pengadilan (Jakarta: Sinar Grafika, 2010) 
yang akurat, bukan dengan pemikiran-pemikiran yang ada. Terlebih perlu perlindungan hukum dan bantuan hukum terhadap perkara-perkara seperti ini.

Di era zaman yang maju saat ini aktivitas perempuan hampir sama dengan aktifitas laki-laki, dengan adanya hal itu semakin banyaknya aktifitas perempuan sehingga berpengaruh terhadap masalah vitalitas seorang perempuan. Dan bila dikaitkan dengan penipuan dan dasar sering terjadi pertengkaran dan perselisihan dalam rumah tangga maka selayaknya kehidupan rumah tangga itu harus didasari landasan saling mengasihi, saling mempercayai, saling membantu untuk menjadikan pasangan itu lebih baik dari sebelumnya sebagai tujuan rumah tangga saling bekerjasama untuk mencapai keluarga yang sakinah mawaddah warahmah.

\section{Penutup}

Penulis menarik kesimpulan bahwa Konsep perkawinan adalah konsep yang universal, dengan tujuan menghalalkan yang haram. Perkawina juga merupakan bentuk ikatan kerjasama antara pria dan wanita. Makhluk biologis seperti manusia tentu memerlukan penyaluran birahi seksualnya, dan ini hanya didapatkan secara halal dalam perkawinan. Dalam hal keperawanan suatu hal yang pasti adalah setelah malam pertama, si istri sudah tidak perawan lagi dan tidak ada satu pun cara untuk membuktikan apakah robeknya selaput dara terjadi sebelum atau pada malam pertama tersebut. Oleh karena itu, penyelesaian konflik ini sangat bergantung pada kepercayaan suami kepada istrinya dan kepedulian terhadap masalah keperawanan serta rasa cinta suami kepada istri.

Keperawanan sebagai menjadi komoditas yang bisa membuat wanita keluar dari persoalan hidup. Keperawanan juga disebut sebagai kehirmatan seorang wanita yang tak ternilai harganya, karena di bawa semenjak dia dilahirkan dimuka bumi ini. Kemudia seorang wanita juga berhak ingin memberikan kepada siapapun tanpa ada interfensi dari siapapun termasuk kontruksi budaya patriarki. Bahwa perempuan juga sangat menghargai arti keperawanan itu sendiri dengan menjaga pergaulan dengan lawan jenisnya. 
Konsep keperawanan sebagai alasan untuk pembatalan pernikahan pada sebuah perkara yakni bahwa pada satu sisi pembatalan pernikahan tersebut merupakan keputusan yang adil namun pada sisi lain tidak cukup adil. Penulis meninjau perkara demikian hanya sekedar tuntutan hukum yang harus ditegakkan guna untuk memutuskan status hukum antara kedua belah pihak. Padahal lebih dari hal itu, terkait akibat putusnya perkawinan bukan hanya persoalan hukum formil yang akan diterima oleh perempuan tersebut tetapi juga persoalan hukum sosial.

Perselisihan yang terjadi di dalam putusan persidangan, seharusnya seorang hakim mendatangkan saksi ahli kesehatan dan juga dalil yang terkait untuk pemeriksaan dalam pembuktiannya. Jadi, dalam hal ini hakim seharusnya perlu untuk mendatangkan saksi ahli untuk meluruskan permasalahan kompleks yang pada hakikatnya tidak memiliki tolak ukur, sehingga asas mempersulit perceraian dapat diterapkan meskipun dalam hal lain perselisihan terjadi sehingga tidak mencapai tujuan pernikahan lagi, namun dengan upaya ini dapat dicegah ataupun dipersulit dengan mendatangkan saksi ahli yang mampu menjawab persoalan dan meluruskan hal tersebut.

\section{DAFTAR PUSTAKA}

Abidin, Slamet, dan Aminuddin Aminuddin. Figh Munakahat I. Bandung: Pustaka Setia, 1999.

A.F, E. Mustofa. Islam Membina Keluarga dan Hukum Perkawinan di Indonesia. Yogyakarta: Kota Kembang, 1987.

Anshary, M. Hukum Perkawinan di Indonesi: Masalah-Masalah Krusial. Yogyakarta: Pustaka Pelajar, 2015.

Anwar, Syamsul. Epistemologi Hukum Islam. Yogyakarta: Penelitian IAIN Sunan Kalijaga Yogyakarta, 2000.

"Arti kata komprehensif - Kamus Besar Bahasa Indonesia (KBBI) Online." Diakses 30 November 2021. https://kbbi.web.id/komprehensif.

As-Subki, Ali Yusuf. Figh Keluarga: Pedoman Bekeluarga Dalam Islam. Jakarta: Amzah, 2010.

Baits, Ammi Nur. "Ternyata Istriku Tidak Perawan." Konsultasi Agama Dan Tanya Jawab Pendidikan Islam (blog). Diakses 30 November 2021. https:// konsultasisyariah.com/22591-ternyata-istriku-tidak-perawan.html.

Barkatullah, Abdul Halim, dan Teguh Prasetyo. Hukum Islam; Menjawab Tantangan Zaman Yang Terus Berkembang. Yogyakarta: Pustaka Pelajar, 2006.

Dikbud, Dep. Kamus Besar Bahasa Indonesia. Jakarta: Balai Pustaka, 1994. 
Fakih, M. Analisis gender dan transformasi sosial. Yogyakarta: Pustaka Pelajar, 2013.

Ghozali, Abdul Rahman. Figh Munakahat. Jakarta: Kencana, 2012.

Hakim, Rahmat. Hukum Perkawinan Islam. Bandung: Pustaka Setia, 2000.

Harahap, M.Yahya. Hukum Acara Perdata Tentang Gugatan, Persidangan, Penyitaan, Pembuktian, dan Putusan Pengadilan. Jakarta: Sinar Grafika, 2010.

Huda, Miftahul. Filsafat Hukum Islam Menggali Hakekat, Sumber dan Tujuan Hukum Islam. Ponorogo: STAIN Po Press, 2006.

Jamhari, Jamhari. Citra Perempuan dalam Islam Pandangan ORMAS Keagamaan. Jakarta: Gramedia, 2003.

Jaziri, Abdurrahman al-. al-Figh 'ala al-Mazahib al-Arab'a, Juz IV. Beirut: Dar al-Fikr, tt. Juwaini, Imam al-Haramain al-. Nihayah al-Mathlab fi Dirayah al-Madzhab, tahqiq, Abdul Azhim Mahmud ad-Dib, cet ke-1, juz, 12. Beirut: Dar al-Minhaj, 2007.

Kodir, Koko Abdul. Metodologi Studi Islam. Bandung: Pustaka Setia, 2014.

"Memperbincangkan Keperawanan, Ketidakadilan Gender - Universitas Muhammadiyah Yogyakarta." Diakses $30 \quad$ November 2021. https://www.umy.ac.id/memperbincangkan-keperawanan-ketidakadilangender.

Mughni, Ali. al Misbah al Munir. Kairo: ttp, tt.

Muslikhati, Siti. Feminisme dan Pemberdayaan Perempuan dalam Timbangan Islam. Jakarta: Gema Insani, 2004.

Mys. "Onheelbare Tweespalt dalam Doktrin dan Yurisprudensi." hukumonline.com. Diakses $30 \quad$ November 2021. https:/ / hukumonline.com/berita/baca/1t4f7ab5bef40e2/ionheelbaretweespalt-i-dalam-doktrin-dan-yurisprudensi.

Najwah, Nurun. Benarkah Nikah Sirri dibolehkan? Dalam Telaah Ulang Wacana Seksualitas. PSW UIN Sunan Kalijaga Yogyakarta: Depag RI, 2004.

P Tong, R, dan Penerjemah A.P Prabasmara. Feminist thought: Pengantar paling komprehensif kepada aliran utama pemikiran feminis. Yogyakarta: Jalasutra, 2006.

Prodjodikoro, Wirjono. Hukum Perkawinan di Indonesia. Bandung: Pionir Jaya, 1986.

Ritzer, George, dan Douglas J. Goodman. Modern Sociological Theory, 6th Edition. Jakarta: Prenada Media, 2003.

Shalih, Syaikh Fuad. Untukmu yang Akan Menikah \& Telah Menikah. Jakarta: Pustaka Al-Kautsar, 2005.

Surjaman, Tjun. Hukum Islam di Indonesia: Pemikiran dan Praktek. Bandung: Remaja Rosdakarya, 1991.

Syarifuddin, Amir. Hukum perkawinan Islam di Indonesia, Antara Figh Munakahat dan Undang-undang Perkawinan. Jakarta: Kencana, 2006.

Thalib, Sajuti. Hukum Kekeluargaan Indonesia, Cet- 5,. Jakarta: UI Press, 1986.

Tihami, Tihami, dan Sahrani Sahrani. Fikih Munakahat: Kajian Fikih Nikah Lengkap. Jakarta: Rajawali Pers, 2014.

Umar, Nassaruddin. Argumen Kesetaraan Jender Perspektif Al-Qur'an. Jakarta: Paramadina, 2001.

Undang-undang perkawinan No 1 Tahun 1974. Bandung: Citra Umbara, 2011.

UU RI No. 1 Th. 1974 Tentang Perkawinan dan Kompilasi Hukum Islam. Bandung: Citra Umbara, 2011.

Zahra, Muhammad Abu. al Ahwal al Syakhsiyyah. Qahirah: Dar al Fikr al 'Arabi, 1957. 
